\title{
MENINGKATKAN HASIL BELAJAR SISWA KELAS IV SD KRISTEN BELSO A2 AMBON DENGAN MENGGUNAKAN MODEL PEMBELAJARAN DOUBLE LOOP PROBLEM SOLVING PADA MATERI PENGUKURAN PANJANG DAN BERAT
}

\author{
Herlina Yacob ${ }^{1}$, Carolina Selfisina Ayal ${ }^{2}$, Johannis Takaria ${ }^{3}$ \\ ${ }^{1,3}$ Prodi PGSD Fakultas Keguruan dan Ilmu Pendidikn, Universitas Pattimura \\ Jalan Ir. M. Putuhena, Kampus Unpatti, Poka, Ambon, Indonesia \\ ${ }^{2}$ Prodi Pendidikan Matematika, Fakultas Keguruan dan Ilmu Pendidikn, Universitas Pattimura \\ Jalan Ir. M. Putuhena, Kampus Unpatti, Poka, Ambon, Indonesia \\ e-mail: ${ }^{2}$ ayal.olly@yahoo.com;
}

\begin{abstract}
Abstrak
Penelitian ini bertujuan untuk mengetahui ada tidaknya peningkatan hasil belajar sswa yang diajarkan dengan menggunakan model pembelajaran Double Loop Problem Solving (DLPS) pada materi pengukuran. Desain penelitian ini adalah pre eksperimental design dengan bentuk One group pre test post test design. Sampel penelitian adalah Kelas IV A yang berjumlah 24 orang. Teknik penelitian yang digunakan adalah teknik tes dan non tes. Analisis data hasil belajar siswa secara deskrptif diperoleh dari hasil presentase dan rata-rata siswa sedangkan untuk mengetahui peningkatan hasil belajar siswa, maka digunakan rumus uji $\mathrm{N}$ - gain. Hasil penelitian menunjukan bahwa penggunaan model pembelajaran Double Loop Problem Solving (DLPS) dapat meningkatkan hasil belajar siswa pada materi pengukuran. $\mathrm{Hal}$ ini didukung dengan analisis pre test dan post test yang menggunakan perhitungan nilai $\mathrm{N}$-gain ternormalisasi dimana $21 \%$ siswa berada pada nilai N-gain dengan kategori Tinggi, 58\% siswa berada pada kategori sedang dan $21 \%$ siswa berada pada kategori rendah.
\end{abstract}

Kata Kunci: Model Pembelajaran DLPS, Hasil Belajar dan Pengukuran

\section{IMPROVING LEARNING OUTCOMES OF SIXTH GRADE IN ELEMENTARY SCHOOL USING DOUBLE LOOP PROBLEM SOLVING LEARNING MODEL IN MEASURE HIGHT AND WEIGHT MATERIALS}

\begin{abstract}
This study aims to determine whether there is an increase in students' learning outcomes taught using Double Loop Problem Solving (DLPS) on the measurement material. The design of this study was a preexperimental design with one group pre test post test design. The research sample was sixth grades which amounted to 24 people. The research techniques used were test and non-test techniques. Analysis of student learning outcomes data descriptively obtained from the results of percentages and average students while to determine the increase in student learning outcomes, we used the N-gain test formula. The results showed that using of the Double Loop Problem Solving (DLPS) learning model could improve student learning outcomes in the measurement material. This is supported by a pre-test and posttest analysis that uses normalized $\mathrm{N}$-gain values where $21 \%$ of students are in the N-gain category with a High category, $58 \%$ of students are in the moderate category and $21 \%$ are in the low category.
\end{abstract}

Keywords: DLPS Learning Model, Learning Outcomens and Measurement

\section{Pendahuluan}

Matematika merupakan mata pelajaran yang diajarkan dari mulai jenjang Sekolah Dasar
(SD) sampai jenjang Sekolah Menengah Atas (SMA). Matematika yang juga merupakan dasar dari beberapa ilmu, seperti statistika, akuntansi, 
fisiska, kimia, dan lain-lain, seharusnya menjadi mata pelajaran yang harus dikuasai siswa. Tuntutan globalisasi di zaman sekarang pun menuntut. Para penerus untuk dapat menguasai ilmu pengetahuandan teknologi. Teknologi yang kini sedang berkembang pesat, baik teknologi informasi dan komonikasi, teknologi elekronika, maupun teknologi mesin, tidak terlepas dari peranan matematika. Matematika yang menyongkong sitem logika dan perhitungan yang pas sehingga teknologi berkembang serta dapat mempermudah pekerjaan manusia seperti yang disebutkan dalam panduan KTSP (BSNP) Permendiknas No. 22/2006 tentang Standar isi, Standar Kompetensi Dasar (SKD) bahwa Matematika merupakan Ilmu Universal yang mendasari perkembangan teknologi modern, mempunyai peranan penting dalam berbagai disiplin dan memajukan daya pikir manusia perkembangan pesat di bidang teknologi dan komonikasi dewasa ini dilandasi oleh perkembangan matematika dibidang aljabar, analisis, teori peluang dan matematika diskrit. Untuk menguasai dan menciptakan teknologi di masa depan diperlukan penguasaan matematika yang kuat sejak dini.

Dalam penelitian ini materi pengukuran panjang dipilih, karena berdasarkan diskusi peneliti sewaktu melakukan observasi di sekolah SD Kristen Belso A2, ternyata materi pengukuran panjang sering di anggap sulit oleh siswa, yaitu saat menghitung pengukuran panjang. Kesulitan yang dialami siswa disebabkan oleh kesalahan siswa dalam menghitung pengukuran panjang. Untuk mengetahui kesalahan seperti apa yang dilakukan siswa, maka dilakukan tes denagn bantuan guru. Tes dilakukan kepada siswa kelas IV dengan jumlah siswa sebanyak 23 orang. Berdasarkan urgensi matematika tersebut setiap siswa diharapkan mampu memahami dan menguasai mata pelajaran ini melalui pembelajaran yang merekaperoleh disetiap jenjang pendidikan. Dalam mata pelajaran matematika terdapat materi pengukuran panjang.

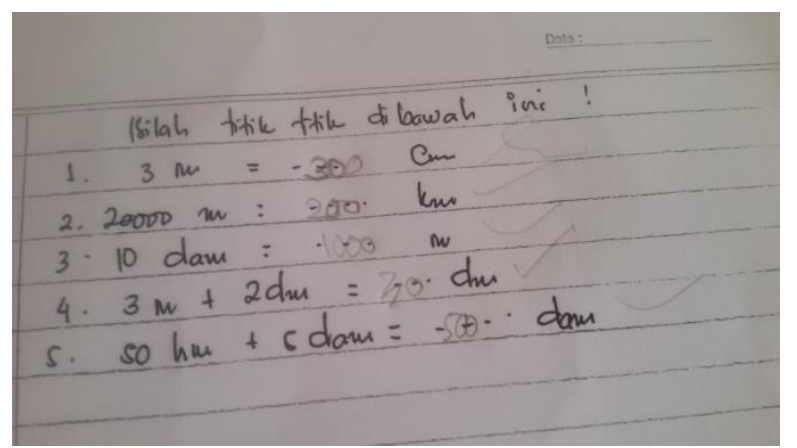

Gambar 1. Hasil kerja siswa
Pada gambar 1 terlihat bahwa hanya no 1 yang mereka kerjakan benar sedangkan pada no 2 , 3, 4 dan 5 mereka kerjakan keliru, karena mereka salah dalam memahami apa yang diterangkan oleh guru sehingga yang mereka kerjakan keliru. Ketika melaksanakan pembelajaran di kelas, peneliti banyak menghadapi permasalahanpermasalahan. Masalah-masalah tersebut yang timbul antara lain pada pelaksanaan proses matematika ketika guru menjelaskan materi pengukuran panjang sebaliknya siswa banyak yang tidak memperhatikan pada pejelasan guru. Siswa cenderung menunjukan sikap bosan dan tidak tertarik dengan pembelajaran. Kemudian ketika guru bertanya apakah siswa sudah mengerti. Hanya sebagian yang menjawab. Proses pembelajaran cendrung berpusat pada guru (teacher oriented). Keadaan seperti ini sudah terjadi berulang kali selama proses pembelajaran dan akibatnya skor yang diperoleh siswa dalam mengerjakan soal-soal latihan rendah dan tidak memuaskan.

Double Loop Problem Solving (DLPS) adalah variasi dari pembelajaran dengan pemecahan masalah dengan penekanan pada pencarian kausal (penyebab) utama dari pertanyaan mengapa, selanjutnya menyelesaikan masalah timbulnya masalah. Berkenan dengan jawaban dengan cara menghilangkan yang menyebabkan munculnya masalah tersebut, DLPS juga merupakan salah satu model yang banyak digunakan untuk menunjang pendekatan pembelajaran yang mengajak peserta didik untuk aktif dalam kegiatan belajar mengajar karena model ini dapat mengajarkan siswa lebih percaya diri kepada kemampuannya dalam berpikir, berbicara, dan menulis dan meningkatkan keterampilan berpikir, berbicara, dan menulis serta mendorong siswa untuk meningkatkan idenya secara verbal dan membandingkan idenya dengan temannya dan sebagainya.

\section{Metode Penelitian}

\subsection{Tipe Penelitian}

Penelitian ini adalah penelitian pre eksperimental design dengan bentuk One group pre test post test design, yaitu desain penelitian yang terdapat pre test sebelum diberi perlakuan dan post test setelah diberi perlakuan, yang digambarkan sebagai berikut:

$$
\mathrm{O}_{1} \mathrm{X} \mathrm{O}_{2}
$$

\section{Keterangan :}

$\mathrm{O}_{1}$ : merupakan pre test 


\section{$\mathrm{O}_{2}$ : merupakan post test}

Rancangan penelitian ini sesuai dengan pendapat Sugiyono (2012) bahwa pre eksperimental design belum merupakan eksperimen sungguh-sungguh karena terdapat variabel luar yang ikut berpengaruh terhadap terbentuknya variable dependen

\subsection{Populasi dan Sampel Penelitian}

Populasi dalam penelitian ini adalah seluruh kelas IV SD Kristen Belso A2 Ambon.

Sampel penelitian adalah Kelas IV A yang berjumlah 24 orang. Penentuan sampel menggunakan teknik purposive sampling sesuai dengan pendapat Sugiyono (2012), bahwa penentuan sampel dengan teknik ini dilakukan dengan pertimbangan tertentu

\subsection{Prosedur Penelitian}

\section{a. Tahap Persiapan}

Pada tahap persiapan, kegiatan-kegiatan yang dilakukan meliputi:

i. Menganalisis standar isi Matematika SD.

ii. Studi kepustakaan penguasaan konsep.

iii. Studi kepustakaan yang berhubungan dengan model pembelajara Doble Loop problem solving.

iv. Penentuan materi Matematika yang akan diteliti

v. Menentukan sekolah dan kelas yang akan dijadikan tempat penelitian dan mengurus surat izin penelitian.

vi. Membuat perangkat pembelajaran berupa Silabus, RPP (Rencana Pelaksanaan Pembelajaran) dan LKS (Lembar Kerja siswa).

\section{b. Tahap Pelaksanaan}

i. Melaksanakan pretest.

ii. Melaksanakan kegiatan pembelajaran menggunakan RPP yang telah disusun.

iii. Melaksanakan post test pada kelas eksperimen dan kelas kontrol.

\section{c. Tahap Akhir}

i. Mengolah data hasil penelitian.

ii. Melakukan analisis hasil penelitian dalam pengambilan kesimpulan.

iii. Membahas hasil penelitian serta menarik kesimpulan dan saran.

iv. Menyusun Laporan penelitian. Penelitian ini adalah jenis penelitian experimen.

\subsection{Teknik Pengumpulan Data}

Teknik penelitian yang digunakan adalah teknik tes dan non tes.

\subsection{Teknik Analisis Data}

Data penelitian yang telah dikumpulkan selanjutnya dianalisis untuk mengetahui nilai hasil belajar siswa terhadap mata pelajarn matematika khususnya materi pengukuran panjang, pada siswa kelas IV SD Kristen Belso A2 Ambon. Data dianalisis secara deskrptif berupa hasil presentase dan rata-rata. Untuk memperoleh hasil belajar siswa, digunakan rumus :

$$
\text { Hasil Belajar }=\frac{\text { Jumlah Skor Perolehan }}{\text { Skor total }} \times 100 \%
$$

Untuk mengetahui peningkatan hasil belajar siswa, maka digunakan rumus uji $\mathrm{N}$-gain sebagai berikut.

$$
\mathrm{g}=\frac{\text { Skor Postes-skor pretes }}{\text { Skor maksimum-skor pretes }}
$$

Hasil perhitungan di interprestasikan dengan menggunakan gain ternomalisasi menurut klasifikasi Hake dalam Meltzer (2002) sebagai berikut:

\begin{tabular}{|c|c|}
\hline N-gain $(\mathbf{g})$ & Kualifikasi \\
\hline $\mathrm{g} \geq 0,70$ & Tinggi \\
$0,30 \leq \mathrm{g}<0,70$ & Sedang \\
$\mathrm{g}<0,30$ & Rendah \\
\hline
\end{tabular}

\section{Hasil dan Pembahasan}

\subsection{Hasil Penelitian}

Berdasarkan tujuan penelitian maka data yang diperoleh dari penelitian ini adalah nilai tes hasil penyelesaian masalah sebelum dan sesudah penyajian materi menggunakan model pembelajaran Double Loop Problem Solving (DLPS) . Beberapa hasil pekerjaan siswa sebelum penggunan model digambarkan sebagai berikut.

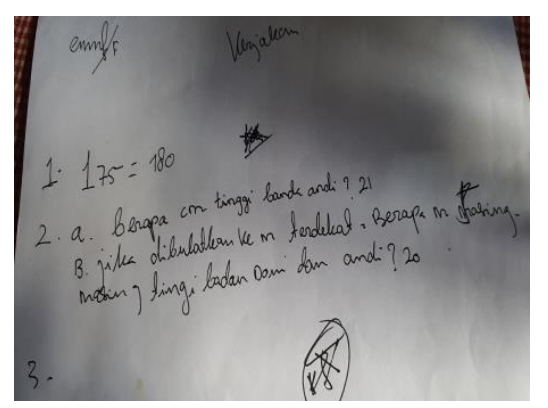

\section{teknik tes dan non tes.}




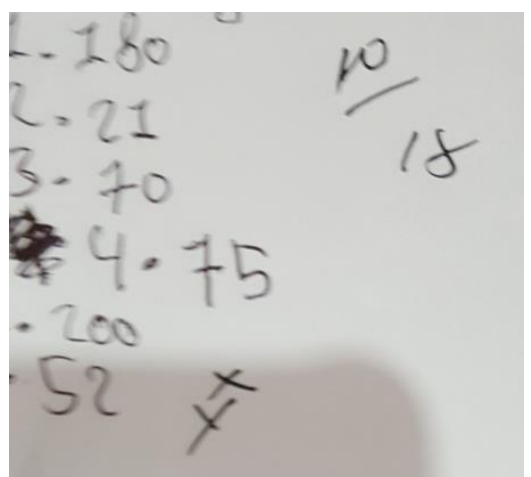

Gambar 2. Hasil kerja siswa

Setelah dilakukan pembelajaran menggunakan Model DLPS terhadap materi pengukuran dilakukan tes, beberapa hasil tes siswa dapat dilihat sebagai berikut.

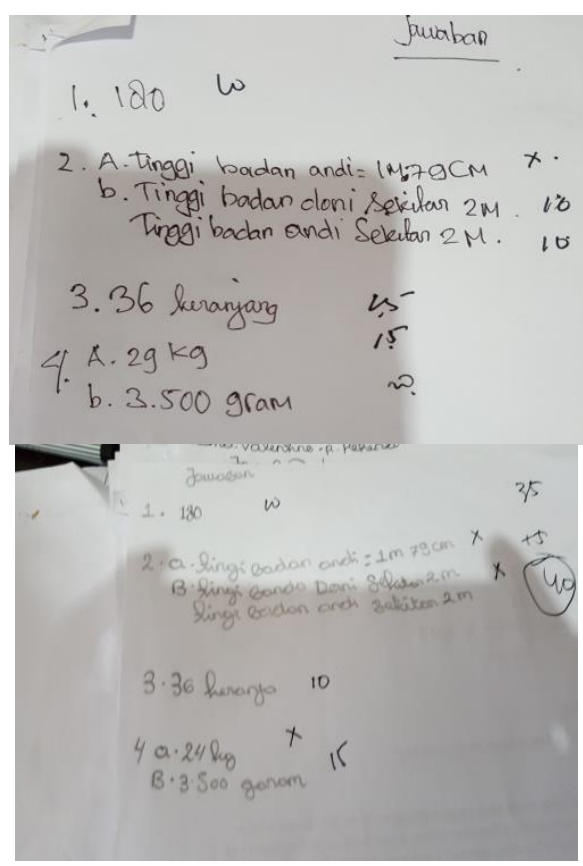

Gambar 3. Hasil tes siswa

Berdasarkan hasil tersebut dapat dilihat bahwa materi pengukuran belum dikuasai dengan baik. Hal ini ditunjukkan dengan pertanyaan yang mengarah pada pembulatan ke satuan terdekat belum dilakukan dengan baik, misalnya ke $\mathrm{m}$ terdekat dan ke cm terdekat.

Hasil pekerjaan siswa selanjutnya dianalisis untuk mengetahui nilai yang diperoleh yang akan menunjukkan tingkat penguasaan siswa. Hasil tes dapat digambarkan sebagai berikut.

Tabel 1. Nilai hasil tes siswa

\begin{tabular}{c|c|c|c}
\hline \multirow{2}{*}{ No } & \multirow{2}{*}{ Nama } & \multicolumn{2}{|c}{ Nilai } \\
\cline { 3 - 4 } & & PreTest & PosTest \\
\hline 1 & $\mathrm{Fl}$ & 15 & 45 \\
2 & $\mathrm{Em}$ & 10 & 40 \\
3 & $\mathrm{Fl}$ & 15 & 46 \\
4 & $\mathrm{Cl}$ & 10 & 45 \\
5 & $\mathrm{Ge}$ & 15 & 45 \\
6 & $\mathrm{Ga}$ & 15 & 80 \\
7 & $\mathrm{Ge}$ & 25 & 70
\end{tabular}

\begin{tabular}{c|c|c|c}
8 & $\mathrm{Ga}$ & 10 & 40 \\
9 & $\mathrm{Mi}$ & 15 & 60 \\
10 & $\mathrm{Me}$ & 10 & 60 \\
11 & $\mathrm{Jo}$ & 35 & 85 \\
12 & $\mathrm{Ti}$ & 10 & 40 \\
13 & $\mathrm{Ru}$ & 10 & 35 \\
14 & $\mathrm{In}$ & 10 & 35 \\
15 & $\mathrm{Pu}$ & 15 & 30 \\
16 & $\mathrm{Qe}$ & 25 & 80 \\
17 & $\mathrm{Qy}$ & 35 & 85 \\
18 & $\mathrm{Ve}$ & 15 & 55 \\
19 & $\mathrm{St}$ & 10 & 40 \\
20 & $\mathrm{Sa}$ & 15 & 35 \\
21 & $\mathrm{Na}$ & 10 & 50 \\
22 & $\mathrm{~Gy}$ & 20 & 80 \\
23 & $\mathrm{Va}$ & 10 & 40 \\
24 & $\mathrm{Ka}$ & 25 & 40 \\
\hline Berdasarkan & Tabel 1. dapat dilihat
\end{tabular}
gambaran nilai hasil belajar materi pengukuran sebelum dan sesudah penggunaan model pembelajaran DLPS. Dari data tersebut dapat dilihat bahwa nilai sebelum diberi perlakukan bervariasi antara 10 dan 35 dan setelah perlakuan nilai bervariasi antara 35 dan 80 . Secara umum gambaran nilai-nilai tersebut dapat dilihat grafik berikut.

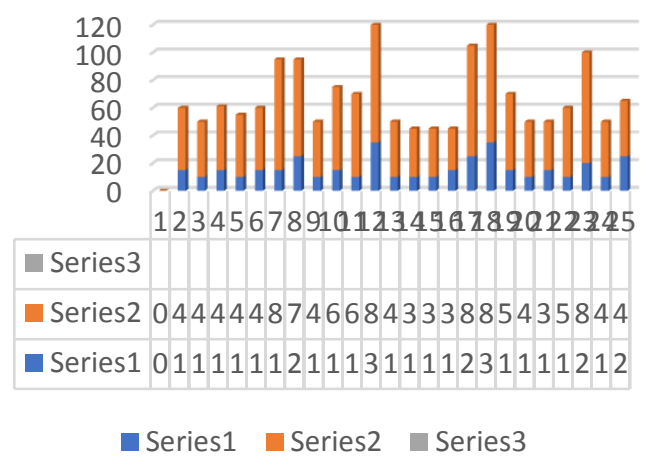

Gambar 3. Grafik Nilai PreTest dan Postest

Berdasarkan pada grafik di atas maka dapat dilihat nilai terendah, nilai tertinggi serta nilai rata-rata sebagaimana tertera pada table berikut

Tabel 2. Sebaran Nilai PreTest dan PosTest

\begin{tabular}{l|l|l}
\hline Kategori & Pre Tes & Post tes \\
\hline Nilai Terendah & 10 & 30 \\
Nilai Tertiggi & 35 & 85 \\
Nilai rata-rata & 16 & 53 \\
\hline
\end{tabular}

Berdasarkan sebaran nilai pada tabel di atas selanjutnya ingin diketahui apakah terdapat peningkatan hasil belajar siswa ketika diajarkan menggunakan model pembelajaran DLPS. Untuk itu data tersebut selanjutnya dianalisis menggunakan rumus $\mathrm{N}$-Gain atau gain ternomalisasi. Berdasarkan rumus N-Gain maka hasil analisis menggunakan Program Excel 2007 dapat dilihat pada tabel berikut.

Tabel 3. Kategori Nilai N-Gain 


\begin{tabular}{c|c|c}
\hline No & Nilai N-Gain & Kategori \\
\hline 1 & 0,35 & Sedang \\
\hline 2 & 0,33 & Sedang \\
\hline 3 & 0,36 & Sedang \\
\hline 4 & 0,39 & Sedang \\
\hline 5 & 0,35 & Sedang \\
\hline 6 & 0,76 & Tinggi \\
\hline 7 & 0,60 & Sedang \\
\hline 8 & 0,33 & Sedang \\
\hline 9 & 0,53 & Sedang \\
\hline 10 & 0,56 & Sedang \\
\hline 11 & 0,77 & Tinggi \\
\hline 12 & 0,33 & Sedang \\
\hline 13 & 0,28 & Rendah \\
\hline 14 & 0,28 & Rendah \\
\hline 15 & 0,18 & Rendah \\
\hline 16 & 0,73 & Tinggi \\
\hline 17 & 0,77 & Tinggi \\
\hline 18 & 0,47 & Sedang \\
\hline 19 & 0,33 & Sedang \\
\hline 20 & 0,24 & Rendah \\
\hline 21 & 0,44 & Sedang \\
\hline 22 & 0,75 & Tinggi \\
\hline 23 & 0,33 & Sedang \\
\hline 24 & 0,20 & Rendah \\
\hline & & \\
\hline
\end{tabular}

Berdasarkan tabel di atas maka dapat ditentukan banyaknya siswa yang berada pada kategori tinggi, rendah dan sedang sebagaimana grafik berikut.

\section{Grafik Kategori Nilai N-Gain}

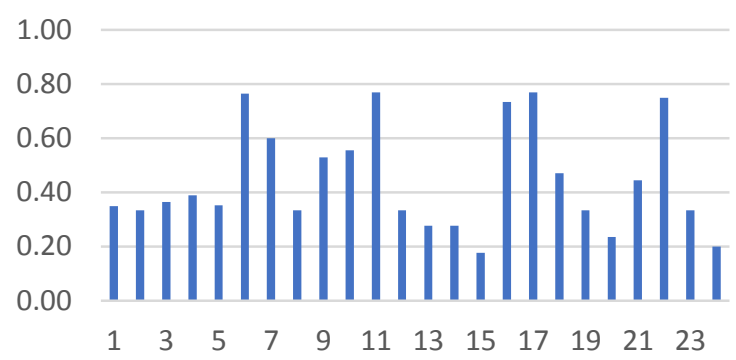

Gambar 4. Grafik sebaran nilai N-Gain

Dari grafik di atas dapat dilihat bahwa terdapat 5 siswa berada pada kategori Tinggi dan Rendah dan 14 berada pada kategori sedang.

\subsection{Pembahasan}

\section{a. Analisis Hasil Belajar Siswa}

Berdasarkan hasil pekerjaan siswa dapat dilihat bahwa terdapat beberapa kelemahan penguasaan materi pengukuran antara lain pemahaman terhadap satuan terdekat. Jika diperhatikan maka apabila satuan terdekat yang dimaksud adalah centimeter maka seharusnya yang dimaksud adalah pembulatan ke satuan terdekat. Pemahaman terhadap konsep pengukuran penting sehingga tidak terdapat kesalahan dalam penentuan nilai akhir. Dalam penelitian ini pengukuran yang dimaksud dibatasi pada konsep pengukuran Panjang dan berat dengan satuan pengukuran yang digunakan adalah satuan pengukuran baku. Hal ini sesuai dengan materi yang diberikan pada saat penelitian dan materi pengukuran panjnag dan berat ini dianggap penting karena berkaitan langsung dengan pengetahuan dan pengalaman siswa seharihari. Menurut Van den Heuvel Panhuizen (2004) dikatakan bahwa pengukuran penting disajikan dalam pendidikan karena pengukuran membandingkan aspek keterampilan praktis yang sangat penting dalam kehidupan sehari-hari, misalnya pengukuran menggunakan mistar, mengukur volume menggunakan gelas merupakan aktifitas siswa sehari-hari dan akan sangt berperan ketika siswa memasuki dunia pedidikan formal. Hal penting selain pemanfaatan pengukuran adalah pengetahuan tentang pengukuran dan sistem pengukuran yang digunakan dalam kehidupan sehari-hari.

Melalui pengalaman sehari-hari melalui aktifitas pengukuran yang dilakukan seharihari misalnya meggunakan depa, hasta atau jengkal dalam mengukur panjang meja siswa dapat diarahkan untuk mendefinisikan konsep pengukuran. Secara umum pengukuran diartikan sebagai membandingkan yang diukur dengan satuan ukuran tertentu yang telah ditetapkan sebelumnya (Dimyati dan Mudjiono, 2002).

Kesalahan yang dibuat siswa selain kurangnya pemahaman terhadap konsep dasar pengukuran dan sistem pengukuran. Hal ini terlihat dari $87 \%$ siswa menyamakan 175 dengan 180, padahal yang diketahui adalah satuan $\mathrm{cm}$ dan yang diharapkan adalah satuan meter. Dalam soal ini tidak ada siswa yang menjawab benar baik sebelum penggunaan model maupun setelah penggunaan model. Dalam hal ini proses berpikir yang diharapkan adalah siswa melakukan pembulatan ke meter terdekat, sehingga jika yang diharapkan jawabannya adalah 2 meter. Dalam hasil pekerjaan yang digunakan dapat dilihat bahwa proses berpikir yang digunakan adalah proses berpikir Semikonseptual.

Proses berpikir semikonseptual merupakan jenis proses berpikir yang cenderung menyelesaikan suatu soal dengan menggunakan konsep tetapi mungkin karena pemahamannya terhadap konsep tersebut belum sepenuhnya lengkap maka penyelesaiannya dicampur dengan cara penyelesaian yang menggunakan intuisi 
(Zuhri, 1998). Hal ini disebabkan karena siswa mengetahui informasi $175 \mathrm{~cm}$ dan juga mengetahui pembulatan terdekat, namun tidak memahami konsep satuan pengukuran yang diharapkan sehingga secara intuitif ia menuliskan 175 sama dengan 180.

Selain itu kesalahan lain adalah siswa tidak memahami masalah yang diberikan. Pemahaman masalah penting sebagai langkah awal proses penyelesaian masalah. Dari hasil pekerjaan siswa pada masalah nomor 2 dapat dilihat bahwa siswa langsung membaca soal kemudian baru menjawab dengan memperhatikan informasi dalam soal, sehingga siswa menjawab $21 \mathrm{~cm}$ tanpa melihat informasi secara keseluruhan. Di sini dibutuhkan pemahaman secara utuh terhadap informasi yang terdapat dalam soal. Selain itu untuk soal nomor 3 dan 4 , sebelum pembelajaran menggunakan model DLPS, rata-rata $93 \%$ siswa tidak memberikan jawaban dan $7 \%$ memberikan jawaban yang salah, dan setelah pembelajaran rata-rata 95\% siswa memberikan jawaban yang benar dan sisanya $5 \%$ memberikan jawaban yang salah.

\section{b. Analisis Hasil Perhitungan Nilai N-Gain} Ternormalisasi

Berdasarkan hasil pengolahan nilai $\mathrm{N}$ Gain untuk mengetahui peningkatan hasil belajar siswa maka dapat dikatakan bahwa terdapat peningkatan dalam hasil belajar materi pengukuran setelah diberikan pembelajarn menggunakan Model Double Loop Problem Solving (DLPS). Hasil peningkatan ini menunjukkan bahwa terdapat kontribusi penggunaan model DLPS dalam peningkatan pemahaman siswa selama proses pembelajaran. Peningkatan ini selain diperoleh melalui perhitungan nilai N-Gain, juga dapat dilihat dari hasil pekerjaan siswa yang menunjukkan jawaban yang tepat pada beberapa butir soal.

Sebaran nilai gain skor yang
menunjukkan sebuah kurva normal
memberikan gambaran bahwa terdapat
peningkatan nilai secara merata pada siswa
yang berada pada kelompok sedang naum
untuk kelompok tinggi dan rendah berada
pada rerata yang sama. Hal ini dapat dilihat
dari perhitungan nilai N-gain sebelum dan
sesudah penggunaan model. Dari hasil
analisis dapat dilihat bahwa terdapat 5 (atau
$21 \%$ ) siswa berada pada kategori tinggi, 14
(atau 58\%) siswa berada pada kategori sedang

dan 5 atau (21\%) siswa berada pada kategori rendah.

Berdasarkan hasil analisis terhadap pekerjaan siswa dapat dilihat bahwa perbedaan hasil pekerjaan sebelum penggunaan model dan sesudah penggunaan model berkisar sekitar $50 \%$, artinya penguasaan materi yang diberikan menggunakan model ini belum memberikan kontribusi perubahan yang signifikan karena perbedaan rerata sebelum dan sesudah penggunaan model hanya $37 \%$. Kelemahan lain dalam penelitian ini berkaitan dengan masalah yang diberikan. Penyelesaian masalah seharusnya mengikuti langkahlangkah penyelesaian masalah yang diawali dengan pengenalan masalah sampai pada evaluasi terhadap hasil penyelesaiannya. Namun jika diperhatikan dari hasil pekerjaan siswa, mereka langsung menentukan jawabannya tanpa menunjukkan pengetahuannya terhadap masalah yang akan diselesaikan. Dengan demikian tidak dapat diketahui lebih jelas bagaimana proses berpikir yang digunakan dalam menyelesaikan masalah.

\section{Kesimpulan}

Berdasarkan hasil dan pembahasan pada bagian sebelumnya maka dapat disimpulkan bahwa penggunaan model pembelajaran Double Loop Problem Solving (DLPS) dapat meningkatkan hasil belajar siswa pada materi pengukuran. Hal ini dapat dilihat dari hasil analisis pre test dan post test yang menggunakan perhitungan nilai N-gain ternormalisasi. Dari hasil analisis terlihat bahwa $21 \%$ siswa berada pada nilai $\mathrm{N}$-gain dengan kategori Tinggi, 58\% siswa berada pada kategori sedang dan $21 \%$ siswa berada pada kategori rendah. Hal lain yang dapat disimpulkan adalah penggunaan model loop ini dalam penerapannya belum terlaksana dengan baik sehingga siswa belum mampu menentukan langkah penyelesaian masalah sesuai dengan teori yang digunakan.

\section{Daftar Pustaka}

Dimyati dan Mudjiono (2002). Belajar dan Pembelajaran. Jakarta: Rineka Cipta dan Depdikbud

Huda (2014) Model- model Pengajaran dan Pembelajaran. Yogyakarta:Pustaka Belajar 
Meltser, D.E (2002). The Relationship between Mathematics Preparation and Conceptual Learning Grains in Physics: A Possible "Hidden Variable" in Diagnostice Pretest Scores. Dalam American Journal Physics, Vol 70 (12), 27 halaman

Sugiyono (2012) Metode Penelitian Pendekatan Kuantitatif, Kualitatif dan R\&D Bandung Alfabeta Bandung

Sukardi, 2011. Metodologi Penelitian Pendidikan,Bumi Aksara,Jakarta.

Van den Heuvel-Panhuizen, M. (2004) Young Children Learn Measurement and Geometry. Netherlands: Freudenthal Institute, Utrecht University

Zuhri, D. (1998). "Proses Berpikir Siswa Kelas II SMPN Pekanbaru Dalam Menyelesaikan Soalsoal Perbandingan berbalik Nilai”.

Yuspriyanti,D.N. (2011) Implementasi Pembelajaran Matematika Dengan menggunakan Doble loop Problem Solving Untuk meningkatkan kompetensi strategis siswa Smp.tesis pada jurnal pembelajaran matematika SPS UPI Bandung: Tidak diterbitkan 